\title{
Nanoparticle from Medinilla speciosa with Various of Encapsulating Agent and Their Antioxidant Activities Using Ferric Reducing Assay
}

\author{
Rissa Laila Vifta*, Fania Putri Luhurningtyas \\ Department of Pharmacy, Universitas Ngudi Waluyo, Ungaran, Jawa Tengah, Indonesia
}

\begin{abstract}
Antioxidants are agents that can reduce free radicals. Parijoto fruit (Medinilla speciosa) contains flavonoids that could act as an antioxidant. However, those flavonoids are water-soluble and show low bioavailability. Nanotechnology is a potential approach to improve the bioavailability of flavonoids from Parijoto fruit. This study was conducted to determine the antioxidant activity of parijoto nanoparticles with variations of the chitosan, alginate, and chitosan/alginate encapsulants. Secondary metabolites of parijoto fruit were using the maceration method. The synthesis of parijoto nanoparticles was conducted using the ionic gelation method with chitosan, alginate, and chitosan/alginate encapsulation. Parijoto nanoparticle size and distribution were characterized using Particle Size Analyzer (PSA). The formation of nanoparticles in colloids was determined as a percent. The antioxidant activity of nanoparticle was evaluated using Ferric Reducing Antioxidant Power (FRAP) method using a UV-Vis spectrophotometer. Chitosan encapsulation produced nanoparticles with a size of $269.3 \mathrm{~nm}$, pdl 0.372 and transmittance $99.379 \%$. Alginate encapsulation produced a particle size of $366.4 \mathrm{~nm}$, pdl 0.589 and transmittance $99.690 \%$. The combination of chitosan/alginate encapsulants produced a particle size of 187.00 $\mathrm{nm}$, pdl 0.239 and transmittance $99.894 \%$. Parijoto nanoparticles obtained from chitosan, alginate, and chitosan/alginate encapsulant showed strong antioxidant powers indicated by $I C_{50}$ values $2.442 \pm 0.047 \mathrm{ppm}, 3.175 \pm 0.169 \mathrm{ppm}$ and $2.115 \pm 0.045 \mathrm{ppm}$, respectively. Altogether, our study shows that parijoto nanoparticles are potent as antioxidant agents.
\end{abstract}

Keywords : Alginate, antioxidant, chitosan, FRAP, Medinilla speciosa, nanoparticle

\section{INTRODUCTION}

Medicinal plants are important sources of antioxidants for life. Antioxidant compounds are found in most fruits and vegetables, including phenolic compounds, carotenoids, anthocyanins, tocopherols (Altemimi, et al., 2017). Antioxidants from plants can protect the body from diseases caused by oxidative processes such as cancer, heart disease, and stroke. Antioxidants regulate and reduce the oxidation process caused by the presence of reactive oxygen species (ROS) (Amari, et al., 2014). Secondary metabolites such as flavonoids and phenolic compounds in natural substances have been reported to have acted

Submitted: November 22, 2019

Revised: January 14, 2020

Accepted: January 14, 2020

*Corresponding author: rissalailavifta@gmail.com 
as an antidote to free radicals (Galvez, 2015).

Parijoto is a Melastomaceae group that has been known to contain flavonoid compounds (Vifta and Advistasari, 2018). Several other genera of Melastomaceae are also known to have antioxidant and antidiabetic activity (Pieroni, et al., 2011). Flavonoids contained in parijoto fruit have the potential to produce antioxidant activity that can increase insulin production. The ability of antioxidants to fight cell damage due to the effects of hyperglycemia, increase and absorption of glucose metabolism can be used as an alternative treatment for DM (Sarian, et al., 2017; Shewasinad, et al., 2019).

Phenolic compounds such as flavonoids have low bioavailability and solubility (Martien, et al., 2012) and bitter taste will be difficult to cover up so that it is limited in food or medicine (Munin and Edwards-Lévy, 2011). In addition, only a small size normal drug can reach the target site of action, while the drug is distributed throughout the body according to physicochemical and biochemical content (Kurniasari and Atun, 2017). So that one of the methods applied to overcome these problems is by making nanoparticle preparations.

The synthesis of nanoparticles will be carried out by the ionic gelation method. The principle of particle formation in this method is the occurrence of ionic interactions between encapsulants and crosslinkers (Ayumi, et al., 2018). The encapsulating agents used in this study were chitosan and alginate-based encapsulants with sodium tripolyphosphate and $\mathrm{CaCl}_{2}$ as a crosslinker. Antioxidant activity can be done through 2,2'-azino-bis (3-ethylbenzothiazoline6-sulfonic acid (ABTS), 2,2-diphenyl-1picrylhydrazyl (DPPH), metal ion chelating, and ferric reducing antioxidant power (FRAP) methods. The FRAP method is used as a parameter of the total antioxidant characteristics (Vijayalakshmi and Ruckmani, 2016). The application of this method is applied by Tahir and Widiastuti (2016); Maryam, et al., (2015); by reacting the transfer of electrons from antioxidants to $\mathrm{K}_{3} \mathrm{Fe}(\mathrm{CN})_{6}$ compound.
This study aimed to analyze the effect of encapsulants on the formation of parijoto nanoparticles through ionic gelation methods. The encapsulating agents used in this study include chitosan, alginate, and combination between chitosan/alginate. Nanoparticles of parijoto analyzed for their antioxidant activity using the FRAP method. The research expected to provide further information about nanoparticle technology in natural materials so that it utilized in the phytomedicine field, specifically as an antioxidant candidate. Antioxidants can prevent diseases arising from oxidative stress such as atherosclerosis, coronary heart disease, stroke, cancer, kidney failure, and the human aging process.

\section{METHODS}

\section{Materials and Instruments}

The parijoto was obtained from the Colo of the Kudus regency with a specification of a 1-3 month harvest period and determined by Ecological and Biosistematic Laboratory, Universitas Diponegoro. The chemicals used include $\mathrm{AlCl}_{3}$, $\mathrm{NaOH} 0.5 \mathrm{~N}, \mathrm{FeCl}_{3} 1 \%, \mathrm{HCl}$ pro analysis, $\mathrm{HCl} 2$ $\mathrm{N}, \mathrm{H}_{2} \mathrm{SO}_{4}$ pro analysis, Magnesium, $\mathrm{NaCl} 10 \%$, $\mathrm{FeCl}_{3} 1 \%$, ammonia 25\%, Trichloroacetate (TCA), ethanol 96\%, FRAP reagent, $\mathrm{FeSO}_{4} .7 \mathrm{H} 2 \mathrm{O}$ (Merck, Darmstadt, Germany), and aquades (Bratachem, Jakarta, Indonesia.

A set of maceration equipment used were a set of sterilizers, centrifugation devices, magnetic stirrers, UV-Vis spectrophotometers (Shimadzu, UVmini-1240), IR spectrophotometers (Perkin Elmer, Frontier FT-IR 96772), and Particle Size Analyzer (PSA) (Malvern, Zetasizer Nano-S90), and Scanning Electron Microscopy (SEM) type Phenom Pro-X.

\section{Extraction of Medinilla speciosa}

The extraction of parijoto (Medinilla speciosa) was done by the maceration method. The parijoto fruit powder (200 gram) macerated 
using 96\% ethanol (1:10) solvent, macerated for three days and continued with remaceration. Macerate was evaporated using a rotary evaporator at an $78^{\circ} \mathrm{C}$ temperature (Tusanti, et al., 2014). The total weight of macerated powder was 600 grams with three times the extraction process.

\section{Formulation of Nanoparticle with Chitosan Encapsulant}

Microencapsulation preparation of Medinilla speciosa was carried out by the ionic gelation method. One gram of chitosan was dissolved in $100 \mathrm{~mL}$ of $1 \%$ glacial acetic acid using a magnetic stirrer so that the chitosan $1 \%$ parent solution was obtained. Next, $80 \mathrm{~mL}$ of $1 \%$ chitosan solution is taken, then little by little added to $100 \mathrm{~mL}$ of parijoto fruit extract into a magnetic stirrer. The mixture was added with a solution with natrium tripolifosfat (NaTPP) (chitosan volume ratio: $\mathrm{NaTPP}=5: 1$ ) and stirring was continued for 30 minutes to produce stable parijoto fruit nanoparticles.

\section{Formulation of Nanoparticle with Alginate Encapsulant}

Among of crude extract was dissolved in $35 \mathrm{~mL}$ of ethanol pro analysis mixed by $15 \mathrm{~mL}$ of distilled water in a $2000 \mathrm{~mL}$ of a glass beaker, alginic acid in $100 \mathrm{~mL} 0.1 \mathrm{M} \mathrm{NaOH}$ and $350 \mathrm{~mL}$ $\mathrm{CaCl}_{2}$ solution (Alginate volume ratio: $\mathrm{CaCl}_{2}=5: 1$ ). The mixture was stirred using a magnetic stirrer for approximately two hours. The colloids from the encapsulation of alginic acid-extract of parijoto fruit were then separated by centrifugation.

\section{Formulation of Nanoparticle with Chitosan/ Alginate Encapsulant}

As much as $2.5 \mathrm{~mL}$ of $0.01 \%$ parijoto fruit extract solution in ethanol $96 \%$ was mixed with 2.5 $\mathrm{mL}$ of chitosan solution in a $\mathrm{pH} 4$ acetate buffer, then mixing and reducing the size using a magnetic stirrer. After mixing for 5 minutes, the TPP solution in distilled water was $2.5 \mathrm{~mL}$ and the sodium alginate solution. $2.5 \mathrm{~mL}$ of distilled water was added to the mixture (Chitosan: Alginate: NaTPP $=1: 1: 1$ ratio). Mixing and reducing the size using a magnetic stirrer was again done for 5 minutes. The ethanol evaporated, and after that, the preparation is stored for one week to observe a stable dispersion system as the chosen formula (Kurniasari and Atun, 2017).

\section{Ferric Reducing Antioxidant Power (FRAP) assay}

Parijoto Fruit extract $(50 \mathrm{mg})$ was weighted and dissolved in $50 \mathrm{~mL}$ of ethanol in a $50 \mathrm{~mL}$ measuring flask until it reached the limit so that a concentration of $1000 \mathrm{ppm}$ obtained. About $40 \mu \mathrm{L}$, $60 \mu \mathrm{L}, 80 \mu \mathrm{L}, 100 \mu \mathrm{L}$ of the stock solution were put into the test tube to obtain concentrations of 2 , 4, 6, 8 and $10 \mathrm{ppm}$, then $1 \mathrm{~mL}$ of phosphate buffer $0.2 \mathrm{~N}$ (pH 6.6) and $1 \mathrm{~mL} \mathrm{~K}_{3} \mathrm{Fe}(\mathrm{CN})_{6}$ were added respectively $1 \%$. Sample then were incubated for 20 minutes at a temperature of $50^{\circ} \mathrm{C}$. After incubation, $1 \mathrm{~mL}$ of $10 \%$ TCA solution was added and centrifuged at $3000 \mathrm{rpm}$ for 10 minutes. After centrifugation, the top layer (if sediment formed) into a $10 \mathrm{~mL}$ measuring flask and adding $0.5 \mathrm{~mL}$ of $\mathrm{FeCl}_{3}$, sufficient with $10 \mathrm{~mL}$ of distilled water in the measuring flask and then absorbed with the maximum wavelength.

\section{Statistical Analysis}

Statistical analysis of data for measuring the $\mathrm{IC}_{50}$ value of each sample using an analysis of variance (ANOVA). One-way analysis of ANOVA uses $95 \%$ confidence. Statistical analysis was performed using the SPSS program. The analysis conducted were determination of the value of the normality and homogeneity of the data, followed by the determination of the least significant difference (LSD) value.

\section{RESULTS}

The extraction process of Parijoto produces extracts and rendement showed in Table 1. Based on the results of volume variations seen from particle 
size, polydispersion index and transmittance values show that the best chitosan formula is $0.2 \% \mathrm{w} / \mathrm{v}$ and NaTPP $0.1 \%$ w/v with a volume ratio of $5: 1$ with a particle size of $269.3 \mathrm{~nm}$ and pdI 0.372 as shown in Table 2. Increasing the volume of chitosan increases the size and distribution of parijoto nanoparticles that have been formulated.

Table 1. Rendement extract of Medinilla speciosa.

\begin{tabular}{cccccc}
\hline \multirow{2}{*}{$\begin{array}{c}\text { Weight of } \\
\text { simplicia (grams) }\end{array}$} & $\begin{array}{c}\text { Weight of extract } \\
\text { (grams) }\end{array}$ & Rendement (\%) & \multicolumn{3}{c}{ Organoleptic } \\
\cline { 4 - 6 } & & & Visual & Texture & Smell \\
\hline 700 & 73.36 & $10.48 \%$ & Brown & Thick & Typical \\
\hline
\end{tabular}

Table 2. Formulation of nanoparticle with chitosan encapsulant.

\begin{tabular}{cccc}
\hline Ratio of chitosan: NaTPP & Particle size $(\mathrm{nm})$ & pdl & Transmittance $(\%)$ \\
\hline $5: 1$ & 269.3 & 0.372 & 99.379 \\
$8: 1$ & 315.7 & 0.493 & 99.127 \\
$10: 1$ & 346.2 & 0.612 & 98.997 \\
\hline
\end{tabular}

The results of the formulation of parijoto nanoparticles with alginate and chitosan/ alginate in Tables 3 and 4 show that the best formula produces nanoparticles with a particle size of $366.4 \mathrm{~nm}$, particle size distribution or polydispersity index (pdI) 0.589 and transmittance value of $99.690 \%$ in the formulation with alginate. The higher the volume added, the larger the size and distribution of the particles produced. Nanoparticles with chitosan/alginate encapsulants produced the best formula with a particle size of $187 \mathrm{~nm}$, pdI 0.239 and transmittance $99.894 \%$.

Table 3. Formulation of nanoparticle with alginate encapsulant.

\begin{tabular}{cccc}
\hline Ratio of Na-alginate: $\mathrm{CaCl}_{2}$ & Particle size $(\mathrm{nm})$ & pdl & Transmittance $(\%)$ \\
\hline $5: 1$ & 366.4 & 0.589 & 99.690 \\
$8: 1$ & 444.5 & 1.000 & 99.578 \\
$10: 1$ & 503.7 & 0.947 & 99.743 \\
\hline
\end{tabular}

Table 4. Formulation of nanoparticle with chitosan/alginate encapsulant.

\begin{tabular}{ccccc}
\hline \multirow{2}{*}{$\begin{array}{c}\text { Ratio of } \\
\text { chitosan:alginate:CaCl } 2\end{array}$} & Visual & $\begin{array}{c}\text { Transmittance } \\
(\%)\end{array}$ & $\begin{array}{c}\text { Particle size } \\
(\mathrm{nm})\end{array}$ & pdl \\
\hline $0.01 ; 0.01 ; 0.01$ & Clear 9 & 9.712 & 190.6 & 0.228 \\
$0.02 ; 0.01 ; 0.01$ & Clear 9 & 9.894 & 187.0 & 0.239 \\
$0.04 ; 0.01 ; 0.01$ & Clear 9 & 9.771 & 188.6 & 0.329 \\
\hline
\end{tabular}

Antioxidant activity was determined by using three groups namely the control group as vitamin $\mathrm{C}$, the parijoto fruit extract group, and the nanoparticle group. Every sample will be tested by the FRAP method. Percent reduction of $\mathrm{Fe}^{3+}$ in vitamin $\mathrm{C}$ (Table 5) is used as a comparison to determine the reduction power of extract test samples (Table 6) and parijoto nanoparticles. The control absorbance used in the measurement of vitamin $\mathrm{C}$ concentration was 0.583 .

Table 5. Reducing power of Vitamin C using FRAP assay.

\begin{tabular}{cccc}
\hline Concentration $(\mathrm{ppm})$ & $\mathrm{Abs} \pm \mathrm{SD}$ & Reducing of $\mathrm{Fe}^{3+} \pm \mathrm{SD}$ & $\mathrm{IC}_{50 \pm} \mathrm{SD}(\mathrm{ppm})$ \\
\hline 1 & $0.165 \pm 0.002$ & $28.359 \pm 0.350$ & \\
3 & $0.334 \pm 0.001$ & $57.289 \pm 0.081$ & $1.959 \pm 0.007$ \\
4 & $0.412 \pm 0.002$ & $70.699 \pm 0.280$ & (Very strong) \\
5 & $0.467 \pm 0.002$ & $80.103 \pm 0.162$ & \\
\hline
\end{tabular}

Table 6. Reducing power of parijoto extract using FRAP assay.

\begin{tabular}{cccc}
\hline Concentration $(\mathrm{ppm})$ & $\mathrm{Abs} \pm \mathrm{SD}$ & ${\text { Reducing of } \mathrm{Fe}^{3+} \pm \mathrm{SD}}$ & $\mathrm{I}_{50 \pm} \mathrm{SD}(\mathrm{ppm})$ \\
\hline 2 & $0.287 \pm 0.0080$ & $21.098 \pm 0.140$ & \\
4 & $0.363 \pm 0.0010$ & $26.701 \pm 0.214$ & $8.898 \pm 0.019$ \\
6 & $0.572 \pm 0.0008$ & $42.024 \pm 0.140$ & (Very strong) \\
8 & $0.653 \pm 0.0008$ & $48.027 \pm 0.140$ & \\
10 & $0.708 \pm 0.0008$ & $51.973 \pm 0.140$ & \\
\hline
\end{tabular}

The results of the antioxidant activity of parijoto nanoparticles with all three encapsulants are presented in Table 7, Table 8 and Table 9. Evaluation of antioxidant activity begins with the determination of the maximum wavelength followed by determining the operating time as a marker of the time needed for the right reaction. An indicator of a compound in reducing $\mathrm{Fe}^{3+}$ ions to $\mathrm{Fe}^{2+}$ ions is characterized by an increase in the absorbance value of the sample (Vijayalakshmi and Ruckmani, 2016).

Table 7. Reducing the power of nanoparticle with chitosan encapsulant using FRAP assay.

\begin{tabular}{cccc}
\hline Concentration $(\mathrm{ppm})$ & Abs $\pm \mathrm{SD}$ & Reducing of $\mathrm{Fe}^{3+} \pm \mathrm{SD}$ & $\mathrm{IC}_{50} \pm \mathrm{SD}(\mathrm{ppm})$ \\
\hline 2 & $0.277 \pm 0.0022$ & $47.51 \pm 0.371$ & \\
4 & $0.337 \pm 0.0012$ & $57.75 \pm 0.214$ & $2.442 \pm 0.047$ \\
6 & $0.397 \pm 0.0008$ & $68.10 \pm 0.140$ & (Very strong) \\
8 & $0.444 \pm 0.0012$ & $76.10 \pm 0.214$ & \\
10 & $0.506 \pm 0.0025$ & $86.85 \pm 0.428$ & \\
\hline
\end{tabular}

Table 8. Reducing the power of nanoparticle with alginate encapsulant using FRAP.

\begin{tabular}{cccc}
\hline Concentration $(\mathrm{ppm})$ & $\mathrm{Abs} \pm \mathrm{SD}$ & Reducing of $\mathrm{Fe}^{3+} \pm \mathrm{SD}$ & $\mathrm{IC}_{50 \pm} \mathrm{SD}(\mathrm{ppm})$ \\
\hline 2 & $0.253 \pm 0.003$ & $43.453 \pm 0.432$ & \\
4 & $0.295 \pm 0.005$ & $50.600 \pm 0.908$ & $3.175 \pm 0.169$ \\
6 & $0.339 \pm 0.011$ & $58.090 \pm 1.882$ & (Very strong) \\
8 & $0.366 \pm 0.002$ & $62.722 \pm 0.262$ & \\
10 & $0.414 \pm 0.001$ & $70.955 \pm 0.198$ & \\
\hline
\end{tabular}


Table 9. Reducing the power of nanoparticle with chitosan/alginate encapsulant using FRAP assay.

\begin{tabular}{cccc}
\hline Concentration $(\mathrm{ppm})$ & $\mathrm{Abs} \pm \mathrm{SD}$ & Reducing of $\mathrm{Fe}^{3+} \pm \mathrm{SD}$ & $\mathrm{IC}_{50 \pm} \mathrm{SD}(\mathrm{ppm})$ \\
\hline 2 & $0.297 \pm 0.001$ & $49.23 \pm 0.253$ & \\
4 & $0.366 \pm 0.002$ & $60.65 \pm 0.345$ & $2.115 \pm 0.045$ \\
6 & $0.422 \pm 0.001$ & $69.92 \pm 0.253$ & (Very strong) \\
8 & $0.495 \pm 0.004$ & $82.01 \pm 0.782$ & \\
10 & $0.556 \pm 0.004$ & $91.99 \pm 0.827$ & \\
\hline
\end{tabular}

The $\mathrm{IC}_{50}$ values of each sample which included parijoto nanoparticles with chitosan, alginate, and chitosan/alginate, parijoto fruit extracts and vitamin $\mathrm{C}$ were then analyzed using the oneway Anava statistically which was started with the determination of normality and homogeneity values. The normality results showed all data were normally distributed $(p>0.05)$, in line with the results of the homogeneity $(p>0.05)$. The result of one-way Anava showed differences in concentration in each treatment expressed with a significance value of less than $0.05(p<0.05)$. The final results of the statistical analysis in Tables 10, 11, and 12 show the significant difference in the antioxidant activity produced by each sample used.

Table 10. Comparison between $\mathrm{IC}_{50}$ of nanoparticle extract within chitosan, parijoto extract, and Vitamin C using LSD statistic.

\begin{tabular}{|c|c|c|c|}
\hline Sample & Comparison & Result & Conclusion \\
\hline Nanoparticle with & Extract of M. speciosa & $p<0.05$ & Significantly \\
\hline chitosan & Vitamin C & & Diferent \\
\hline
\end{tabular}

Table 11. Comparison between $\mathrm{IC}_{50}$ of nanoparticle extract within alginate, parijoto extract, and Vitamin C using LSD statistic.

\begin{tabular}{|c|c|c|c|}
\hline Sample & Comparison & Result & Conclusion \\
\hline \multirow[t]{2}{*}{ Nanoparticle with alginate } & Extract M. speciosa & $p<0.05$ & Significantly \\
\hline & Vitamin C & & Diferent \\
\hline
\end{tabular}

Table 12. Comparison between $\mathrm{IC}_{50}$ of nanoparticle extract within chitosan/alginate, parijoto extract, and Vitamin C using LSD statistic.

\begin{tabular}{|c|c|c|c|}
\hline Sample & Comparison & Result & Conclusion \\
\hline Nanoparticle with & Extract of M. speciosa & $p<0.05$ & Significantly \\
\hline chitosan/alginate & Vitamin C & & diferent \\
\hline
\end{tabular}

\section{DISCUSSION}

From the extraction of Parijoto fruit, we obtained an extract with percent yield of $17.529 \%$ and moisture content of $0.38 \%$. The maceration method will help separate the compounds in simplicia with the diffusion method which will balance the solution inside and outside the cell until the balance condition was reached. Maceration methods are relatively safe and prevent damage to certain secondary metabolite compounds, especially flavonoids. Sa'adah, et al. (2017) show that the flavonoid group has a glycoside bond with a sugar molecule that will break or break at high temperatures. The increase in temperature causes phenolic levels to increase to a certain temperature and then decrease with increasing temperatures.

The nanoparticles from Medinilla speciosa were made by ionic gelation using chitosan and alginate-based polyanions as encapsulants. In addition to simple preparation methods, chitosan and alginate also have biodegradable, biocompatible, food-grade, and low toxicity properties. The results of research with chitosan encapsulation obtained by nanoparticles with a size of $269.3 \mathrm{~nm}$, pdI 0.372 and transmittance $99.379 \%$. Alginate encapsulation produces a particle size of $366.4 \mathrm{~nm}$, pdI 0.589 , transmittance $99.690 \%$. Nanoparticles with chitosan/alginate encapsulants produced a particle size of $187.00 \mathrm{~nm}$, pdI 0.239 and transmittance $99.894 \%$. The small particle size is influenced by the conditions of $\mathrm{pH}$, volume, duration, and speed of mixing. The result of small particle size according to Taurina, et al., (2017) research due to increased stirring time will increase the intensity of the solvent molecule to come into contact with chitosan so that the resulting particle size gets smaller.

Parijoto fruit extracts encapsulated with chitosan, alginate and chitosan/alginate have higher antioxidant activity because the delivery system from encapsulants and crosslinkers can absorb the secondary metabolites well (Charernsriwilaiwat, et 
al, 2013). Based on research (Ningsih, et al., 2017) mangosteen peel extract which is encapsulated using chitosan has an antioxidant activity which is proportional to the particle size, which is the smaller the particle size, the greater the surface area so that the ability to bind to the target is greater. Determination of the activity of extracts and nano extracts of Parijoto fruit using FRAP method with the principle that is the ability of a compound to reduce $\mathrm{Fe}^{3+}$ ions to $\mathrm{Fe}^{2+}$. The formed of $\mathrm{Fe}^{2+}$ ion is the cumulative antioxidant capacity present in a sample without indicating the type of active compound. Increasing the concentration in the sample shows the ability to reduce with a marked increase in $\mathrm{Fe}^{2+}$. This is shown by the color change from yellow to Prussian blue which is getting thicker (Vijayalakshmi, et al., 2016).

The strength of the sample reduction power is determined based on electron donations in reducing ferric cyanide $\left[\mathrm{Fe}(\mathrm{CN})_{6}\right]^{3-}$ to ferrocyanide $\left[\mathrm{Fe}(\mathrm{CN})_{6}\right]^{4-}$. The yellow $\mathrm{Fe}^{3+}$ complex is reduced to a pale green $\mathrm{Fe}^{2+}$ complex. The more concentrated the color formed, the higher the reduction in $\mathrm{Fe}^{3+}$ (Irma and Suryanto, 2016). Parijoto nanoparticles with chitosan/alginate encapsulants produce the best antioxidant activity with $\mathrm{IC}_{50}$ values of $2.115 \pm 0.045$ ppm. Smaller particle size results in having better antioxidant activity. The encapsulation process results in the absorption process of flavonoid active compounds on the surface of nanoparticles so that the resulting bioactivity is increasing (Sarian, et al., 2017).

Hydroxy groups in flavonoids as antioxidants have a mechanism of donating hydrogen and electrons to free radicals. The hydroxyl group in chirping B can shift electrons to produce radicals that are more stable and not reactive so that they can bind to target molecules such as enzymes that match the pattern (Arifin and Ibrahim, 2018). A pair of hydroxy groups in positions $\mathrm{C}-3^{\prime}$ and $\mathrm{C}-4^{\prime}$ or $\mathrm{C}-4{ }^{\prime}$ and $\mathrm{C}-5$ (Catechol) on flavonoid compounds can increase antioxidant activity in the FRAP method (Sarian, et al., 2017).
The results of statistical analysis using one-way Anava shows the antioxidant activity of parijoto nanoparticles with chitosan, alginate, and chitosan/alginate yielding significantly different values through the significance value $(<0.05)$ of the extract. These results indicate that the formation of nanoparticles with chitosan and alginate-based capsules can increase the antioxidant activity of the extract preparation. The statistical results also show the percentage of reducing nanoparticles to $\mathrm{Fe}^{3+}$ to $\mathrm{Fe}^{2+}$ has a significance value $<0.05$. Ramadon and Mun'im (2016) stated that the development of new drug delivery systems such as nanoparticles is able to control the release of drugs so that their pharmacological activities become better.

\section{CONCLUSION}

Encapsulation of parijoto using various of encapsulating agents increase their antioxidant activities. Parijto nanoparticles with chitosan produced a particle size of $269.3 \mathrm{~nm}$, pdI 0.372 and transmittance $99.379 \%$. Nanoparticles with alginate yield particle size of $366.4 \mathrm{~nm}$, pdI $0.589,99.690 \%$ transmittance, and chitosan/alginate encapsulation produced a particle size of $187.00 \mathrm{~nm}$, pdI 0.239 , and transmittance $99.894 \%$. The antioxidant activity of parijoto nanoparticles showed strong antioxidant power indicated by $\mathrm{IC}_{50}$ values respectively $2.442 \pm 0.047 \mathrm{ppm}, 3.175 \pm 0,169 \mathrm{ppm}$, and $2.115 \pm 0.045 \mathrm{ppm}$ for nanoparticles with chitosan, alginate, and chitosan/alginate with very strong antioxidant categories. All of the nanoparticles have antioxidant activities bigger than parijoto crude extract.

\section{ACKNOWLEDGEMENT}

Author thank the Ministry of Technology Research And Higher Education of Indonesia (KEMENRISTEK-DIKTI) for providing material support in the form of PDP funding in 2019 so that this research can be carried out well. 


\section{REFERENCES}

Altemimi, A., Lakhssassi, N., Baharlouei, A., Watson, D.G. and Lightfoot, D.A., 2017, Phytochemicals: Extraction, isolation, and identification of bioactive compounds from plant extracts, Plants, 6(4), 42.

Amari, N.O., Bouzouina, M., Berkani, A. and Lotmani, B., 2014, Phytochemical screening and antioxidant capacity of the aerial parts of Thymelaea hirsuta L., Asian Pacific Journal of Tropical Disease, 4(2), 104-109.

Arifin, B. and Ibrahim, S., 2018, Structure, Bioactivity and Antioxidant of Flavonoid, Jurnal Zarah, 6(1), 21-29.

Ayumi, D., Sumaiyah, S. and Masfria, M., 2018, The preparation and characterization of ethanol extracts of dragon tail leaves (Rhaphidophora pinnata (L.f.) Schott) using the ionic gelation method, Talenta Conference Series: Tropical Medicine (TM), 1(3), 29-33.

Charernsriwilaiwat, N., Rojanarata, T., Ngawhirunpat, T., Sukma, M. and Opanasopit, P., 2013, Electrospun chitosan-based nanofiber mats loaded with Garcinia mangostana extracts, International Journal of Pharmaceutics. Elsevier B.V., 452(1-2), 333-343.

Galvez, M.A.C., 2015, Evaluation of DPPH Free Radical Scavenging Activity and Phytochemical Screening of Selected Folkloric Medicinal Plants in Tinoc, Ifugao, Cordillera Administrative Region, Philippines, International Journal of Scientific and Research Publications, 5(12), 440445.

Irma, L. and Suryanto, E., 2016, Pengaruh Lama Perendaman Terhadap Aktivitas Antioksidan dari Empelur Sagu Baruk (Arenga microcharpha), Chem. Prog, 9(1), 25-34.

Kurniasari, D. and Atun, S., 2017, The preparation and characterization of fingerroot (Boesenbergia pandurata) etanol extract nanoparticles with various citosan compotition, Jurnal Sains Dasar, 6(1), 31.
Farida, V. and Sari, D.P., 2012, Technology developments nanoparticles as drug delivery systems, Majalah Farmaseutik, 8(1), 133-144.

Maryam, S., Baits, M. and Nadia, A., 2015, The Determination of Antioxidant Activity of Moringa Oleifera Lam. Moringa Leaf Ethanol Extract Using FRAP (Ferric Reducing Antioxidant Power) Method, Jurnal Fitofarmaka Indonesia, 2(2), 115-118.

Munin, A. and Edwards-Lévy, F., 2011, Encapsulation of natural polyphenolic compounds, a review, Pharmaceutics, 3(4), 793-829.

Ningsih, N., Yasni, S. and Yuliani, S., 2017, Nanoparticle of Red Mangosteen Peel Extract Synthesis and the Functional Characteristic of its Encapsulated Product, Jurnal Teknologi dan Industri Pangan, 28(1), 27-35.

Pieroni, L.G., Rezende, F.M.D., Ximenes, V.F. and Dokkedal, A.L., 2011, Antioxidant activity and total phenols from the methanolic extract of Miconia albicans (Sw.) Triana leaves, Molecules, 16(11), 9439-9450.

Sa'adah, H., Nurhasnawati, H. and Permatasari, V., 2017, Effect of the extraction method on the concentration of flavonoids ethanol extract of onion dayak bulbs (Eleutherine palmifolia (L.) Merr) using spectrophotometry, Borneo Journal of Pharmascientech, 01(01), 1-9.

Sarian, M.N., Ahmed, Q.U., So'ad, M., Zaiton, S., Alhassan, A.M., Murugesu, S., Perumal, V., Mohamad, S., Akilah, S.N., Khatib, A. and Latip, J., 2017, Antioxidant and antidiabetic effects of flavonoids: A structure-activity relationship based study. BioMed research international, 2017.

Shewasinad, A., Bhoumik, D., Hishe, H.Z. and Masresha, B., 2019, Antidiabetic Activity of Methanol Extract and Fractions of Thymus schimperi Ronniger Leaves in Normal and Streptozotocin Induce Diabetic Mice, Iranian J Pharmacol Ther., $1,8$.

Tahir, M., H., A. C. and Widiastuti, H. 2016. Uji Aktivitas Antioksidan Buah Semangka (Citrullus 
lanatus) dengan Metode FRAP, As-syifaa Jurnal Farmsasi, 08(01), pp. 31-38.

Taurina, W., Sari, R., Hafinur, U.C., Wahdaningsih, S. and Isnindar, I., 2017, Optimization of Stirring Speed And Stirring Time Toward Nanoparticle Size of Chitosan-Siam Citrus Peel (Citrus nobilis L. var Microcarpa) 70\% Ethanol Extract, Majalah Obat Tradisional (Traditional Medicine Journal), 22(1), 16-20.

Tusanti, I. and Johan, A., 2014, Sitotoksisitas in vitro ekstrak etanolik buah parijoto (Medinilla spe- ciosa) terhadap sel kanker payudara T47D, Jurnal Gizi Indonesia, 2(2), 53-58.

Vifta, R.L. and Advistasari, Y.D., 2018, Pytochemical Screening, Characterization, and Determination of Total Flavonoids Extracts and Fractions of Parijoto Fruit (Medinilla speciosa B.), In Prosiding Seminar Nasional Unimus (Vol. 1).

Vijayalakshmi, M. and Ruckmani, K., 2016, Ferric reducing anti-oxidant power assay in plant extract, Bangladesh Journal of Pharmacology, 11(3), 570-572. 